\title{
Permasalahan Cita-cita Anak yang Menyebabkan Kelangkaan Petani Masa Depan
}

\author{
Albertus Galih Pamuji \\ Universitas Kristen Satya Wacana Salatiga, Salatiga \\ Email: 292015088@student.uksw.edu
}

\begin{abstract}
Every child has a dream. Nowadays, the ideals of children tend not to be interested in the agricultural sector it becomes a big problem. If young generations are not interested in agriculture then it can cause problems in the future. The profession as a farmer is considered primitive and does not guarantee welfare. In order to attract the interest of children, it is necessary to improve development in the agricultural sector, so that farmers can gain prosperity. Schools, teachers, and parents hold important roles to support children so that they have the passion and willingness to understand the agriculture sector. It needs early effort to introduce to children anything about agriculture so that the love and tolerance of children can grow. Giving scholarships to children for continuing their education can also be done to increase the number of farmers in the future.
\end{abstract}

Keywords: Scarcity of Farmer, Agricultural Development, Developing Teenagers' Interests, Children Interest

\section{PENDAHULUAN}

Sebagai negara agraris Indonesia belum mampu terlepas dari masalah pangan terutama ketersediaan beras. Belakangan ini Indonesia sering melakukan impor beras dari negara tetangga. Masalah ketersediaan beras amat bergantung dari produktivitas para petaninya. Banyak faktor yang memengaruhi terpuruknya produktivitas beras di tanah air. Diantaranya pengolahan lahan yang masih secara tradisional atau belum tersentuh teknologi, kurangnya ketersediaan modal untuk para petani, kualitas SDM yang masih rendah, faktor alam (cuaca buruk) dan sebagainya.

Disamping itu, Indonesia memiliki keuntungan untuk menumbuh-kembangkan sektor pertanian. Lahan pertanian yang luas masih banyak tersedia di tanah air, terutama di luar pulau Jawa. Selain itu pemerintah saat ini sedang gencar-gencarnya dalam membangun infrastruktur terutama di daerah yang selama ini masih tertinggal, terutama di daerah pedalaman seperti di Papua. Indonesia juga diuntungkan dengan kondisi iklimya serta tanahnya yang subur. Sebagai negara tropis, Indonesia memiliki potensi yang sangat besar untuk pembangunan pertanian dan menjadikan sektor ini sebagai dongkrak untuk pembangunan nasional.

Pertumbuhan pertanian Indonesia cukup berhasil di era tahun (1970)-an, kala itu pemerintah berhasil membangun pertanian yang terintregasi cukup baik ke dalam kebijakan ekonomi makro. Salah satu hasil dari 
pembangunan pertanian masa itu adalah swasembada beras di tahun 1984.

Profesi sebagai seorang petani saat ini juga kurang diminati oleh anak-anak muda. Persepsi mereka memandang bahwa profesi sebagai petani adalah pekerjaan kasar untuk orang-orang pedesaan. Kurangnya kesadaran kaum muda akan besarnya peranan petani bagi kehidupan mereka membuat profesi ini dikesampingkan. Selain itu kesejahteraan para petani membuat orang mengurungkan niat untuk menjadi petani. Padahal, apabila dunia pertanian ini ditekuni dan terus dikembangakan akan mampu mendongkrak perekonomian Indonesia.

Rata-rata anak mulai dari usia dini apabila ditanya soal cita-cita anak akan menjawab dokter, guru, polisi, pilot, tentara dan sebagainya. Jarang, bahkan hampir tidak pernah seorang anak mengatakan bahwa dirinya kelak akan menjadi seorang petani. Bahkan seorang petani pun tidak ingin apabila kelak nanti anaknya menjadi petani seperti orang tuanya. Pesisme orang tua akan kesuksesan anak apabila menekuni bidang pertanian membuat profesi sebagai petani akan terancam.

Padahal segalanya berhubungan dengan pertanian. Bagaimana hubungan antara petani dengan kemajuan sepak bola serta bulu tangkis nasional? Jawabannya, petani menghasilkan padi, padi diolah menjadi beras yang kemudian dikonsumsi oleh para atlit sepak bola. Apabila kebutuhan pangan para atlit terpenuhi maka mereka akan memiliki tubuh yang bugar sehingga dapat berlatih dan berlaga dengan kondisi yang prima. Padi yang diselep akan menghasilkan ampas yang sering disebut dedak. Dedak biasanya digunakan untuk pakan unggas. Apabila pakan unggas terpenuhi dengan baik maka pertumbuhan unggas pun dapat maksimal, sehingga mampu menghasilkan bulu yang dapat digunakan sebagai shuttle cock. Dan apabila industri shuttle cock dapat berkembang dengan baik maka anak-anak dapat membelinya dengan harga yang murah untuk berlatih dan pada akhirnya berdampak pada prestasi bulu tangkis nasional.

Sektor pertanian juga memiliki hubungan yang sangat strategis dengan kehidupan kita, terutama untuk pembangunan ekonomi suatu bangsa. Pertanian berperan penting dalam penciptaan dan ketersediaan pangan nasional (food security), hal ini erat pula kaitannya dengan ketahanan sosial (sosio security). Pertanian juga menjaga stabilitas ekonomi, stabilitas politik, dan keamanan serta ketahanan nasional. Dari sektor pertanian akan menghasilkan berbagai bahan pokok untuk dapat meningkatkan pertumbuhan sektor industri dan jasa. Sektor pertanian menjadi pasar yang potensial untuk barang-barang hasil industri, selain itu banyak tenaga kerja yang semestinya dapat terserap ke dalam sektor pertanian. Sekitar $45 \%$ tenaga kerja bergantung pada pertanian primer, maka tidak heran apabila sektor pertanian menjadi basis pertumbuhan di perdesaan .

Melihat begitu banyaknya manfaat yang dapat didapat apabila sektor pertanian ini mampu berkembang, amat sangat disayangkan apabila kelak Indonesia kekurangan petani masa depan. Pembangunan pertanian masih mengalami permasalahan-permasalahan yang menghambat perkembangannya, baik masalah secara makro maupun secara mikro. Daya saing pertanian Indonesia dengan negaranegara lain khusunya di Asia masih tertinggal. Berbagai upaya perlu dilakukan untuk memajukan sektor pertanian, agar kelak negara kita dapat bersaing dengan negara lain. Apabila sektor pertanian menjadi maju, anak muda yang semula acuh akan mulai mengandrungi sektor pertanian ini (Saptana \& Rahman, 2015).

\section{HASIL PENELITIAN DAN PEMBAHASAN}

\section{Permasalahan Pertanian Indonesia}

Dalam beberapa puluh tahun kedepan negara kita akan kekurangan petani. Saat ini sektor pertanian yang menyerap sebagian besar tenaga kerja belum mampu memberi kontribusi yang maksimal untuk negara, baik itu menyokong kebutuhan pangan nasional atau meningkatakan perekonomian negara. Memiliki banyak petani belum bisa menjamin kemakmuran, lalu bagaimana jika kekurangan petani? Sejatinya, kurangnya minat anak untuk menjadi petani disebabkan karena penghasilan petani yang tidak menentu. 
Umumnya orang ingin bekerja dengan upah yang sudah pasti dan terjamin. Orang tua mengharapkan agar anak mereka menjadi orang yang sukses, beberapa profesi yang mereka anggap mendatangkan kesuksesan antara lain tentara, polisi, guru, serta pegawai kantoran. Gaji yang besar merupakan tolak ukur kesuksesan orang pada umumnya, sedangkan tidak ada yang menggaji petani setiap bulannya.

Pendapatan atau penghasilan menjadi salah satu indikator kesuksesan manusia. Pendapatan digunakan sebagai tolak ukur dalam menilai suatu keberhasilan suatu usaha dan juga faktor yang menentukan kelangsungan suatu usaha. Dalam sektor petanian luas lahan mempengaruhi pendapatan seorang petani. Petani yang memiliki lahan yang lebih luas dibanding petani lain akan memiliki penghasilan yang lebih besar, karena berpeluang memproduksi hasil pertanian lebih banyak. Akan tetapi apabila lahan tersebut tidak diolah secara optimal akan memberikan kerugian bagi petani.

Perlu dilakukan upaya pengawasan terhadap faktor produksi seperti bibit, obatobatan dan tenaga kerja. Selain itu, ketersediaan untuk mengelola lahan yang luas juga menjadi faktor penting untuk memperoleh pendapatan. Salah satu faktor yang merangsang petani untuk meningkatkan hasil produksinya adalah harga, sebab dengan bersaing dan tingginya harga maka pendapatan yang diterima petani akan meningkat pula. Dalam mengelola lahan petani memerlukan modal atau biaya produksi. Jumlah kecilnya produksi ditentukan oleh besar kecilnya biaya produksi.

Menjadi petani memang bukan perkara mudah, banyak tantangan dan hambatan yang harus dilalui. Indonesia yang dahulu sempat dikenal sebagai Lumbung Padi Asia kini telah telah tergantikan perannya oleh negara lain seperti Thailand dan Vietnam. Pertumbuhan produksi beras dalam negeri tidak seimbang dengan pertumbuhan warga negaranya, sehingga mengakibatkan produksi beras dalam negeri tidak lagi mampu mencukupi kebutuhan pangan para rakyatnya. Apakah Indonesia akan terus menggantungkan diri terhadap negara lain untuk memberi makan rakyatnya?
Sedangkan tanah Indonesia sangat potensial untuk kegiatan cocok tanam.

Pandangan sebagian orang yang menganggap profesi petani sebagai profesi yang primitif atau tertinggal sejatinya adalah pandangan yang keliru. Pandangan tersebut muncul akibat pengamatan yang dilakukan hanya sepintas saja, padahal profesi sebagai petani merupakan profesi yang potensial apabila ditekuni. Pola pikir masyarakat tentang petani yang primitif dan tertinggal merupakan akibat dari modernisasi. Konsep modernisasi berarti upaya yang bertujuan untuk menyamai standar yang dianggap lebih modern. Dari segi peralatan yang digunakan, pertanian memang belum sepenuhnya menggunakan teknologi yang modern. Peradaban semakin maju, alatalat cangkih yang dapat digunakan untuk menyokong sektor pertanian pun sudah tersedia. Petani perdesaan sudah saatnya untuk mendapatkan dan bisa mengoperasikan alatalat tersebut.

Indonesia telah dianugerahi Tuhan tanah yang subur dan luas, hanya saja rakyatnya kurang mensyukuri anugerah Tuhan dengan tidak mengoptimalkan potensi yang ada. Lahan-lahan pertanian saat ini bukannya ditanami padi melainkan ditanami oleh perusahaan industri dan perumahan. Industri berkembang begitu pesat dan sudah mengambil sebagian besar lahan pertanian di Pulau Jawa. Banyak sumber daya alam dan lingkungan yang sudah rusak, hal ini disebabkan oleh tingkat pertambahan penduduk serta pola penyebarannya yang kurang seimbang dengan pola ketersedian sumber daya alam serta daya dukung lingkungan. Tingkat pertumbuhan penduduk yang pesat tidak mampu diimbangi dengan ketersedian lahan pertanian, palahan lahan pertanian terus dipakai untuk kebutuhan sektor non pertanian.

Adanya pertambahan penduduk akan memerlukan pertambahan kebutuhan sandang, pangan dan papan. Ketidakseimbangan pertambahan penduduk dengan pertambahan kebutuhan sangat mempengaruhi keadaan lingkungan hidupnya, yaitu lingkungan akan dieksploitasi besar-besaran untuk memenuhi kebutuhan hidup. Akibatnya daya dukung lingkungan akan berkurang dan terjadi kerusakan lingkungan yang serius (Arifin, 
2004). Kebijakan migrasi yang dilakukan dirasa kurang menguntungkan untuk mendobrak sektor pertanian, karena rata-rata penduduk yang bermigrasi lebih memilih ke area industri dengan kemampuan lahan yang rendah.

Sektor pertanian di Indonesia mengalami berbagai permasalahan dan tantangan. Beberapa halangan yang dapat menghambat perkembangan pertanian di Indonesia antara lain adalah: pertama, belum terciptanya usaha teknis dan ekonomis dalam sektor pertanian sehingga membuat daya saing menjadi kurang bergairah. Kedua, adalah tidak stabilnya kondisi ekonomi, politik, dan keamanan dalam negeri sehingga membuat para investor enggan untuk menanamkan modalnya untuk sektor pertanian. Ketiga, kondisi infrastruktur yang masih kurang baik, karena pada dasarnya sektor pertanian sangat bergantung pada ketersedian infrastruktur yang memadahi. Keempat, kualitas sumber daya manusia (SDM) yang masih relatif rendah. Kelima, kebijakan pemerintah belum berpihak kepada petani. Walaupun upaya revitalisasi sudah dicanangkan, namun pada faktanya masih ada inkonsistensi kebijakan.

Kenaikan harga yang tidak menentu juga sering dirasakan oleh masyarakat, apabila pemerintah tidak mampu melakukan langkah antisipatif maka dikhawatirkan akan terjadi gejolak sosial dan politik yang tidak remeh. Besarnya peran pertanian belum dapat dimanfaatkan secara optimal oleh negaranegara berkembang, Indonesia salah satunya. Disamping itu, Indonesia juga tidak terlepas dari berbagai isu terkait pertanian global, diantaranya: peningkatan biaya dan pajak impor (AFTA\&WTO), kurangnya investor asing, biaya inovasi teknologi yang masih mahal, prasyarat kesehatan pangan, dan referensi untuk produk impor.

Daya saing sektor pertanian Indonesia masih tergolong rendah. Daya saing merupakan kemampuan suatu sektor, industri atau perusahaan untuk mampu bersaing serta mampu mencapai pertumbuhan secara berkelanjutan, dengan memperoleh laba dari hasil usahanya (Arief) dalam Ningsih \& Kurniawan (2016). Kemampuan negara dalam mengelola sumber daya pertanian masih belum mampu dioptimalkan. Negara harus mampu menguasai faktor produksi, seperti tenaga kerja dan infrastruktur. Disamping itu penguasaan pasar domestik juga diperlukan untuk memasarkan produk maupun jasa. Kerjasama yang baik antara produsen dan pemasok barang-barang pendukung di sektor pertanian juga menjadi kunci untuk meningkatkan daya saing. Selain itu kondisi pemerintahan yang baik di suatu negara perlu diciptakan, agar pertanian dapat diorganisasi, dan dikekola untuk dapat menguasai pasar domestik.

Guna meningkatkan daya saing di sektor pertanian, perlu adanya dukungan seperti daya dukung lahan. Pengertian dari daya dukung lahan sendiri adalah kemampuan suatu lahan untuk dapat digunakan guna memenuhi kebutuhan manusia terutama pemenuhan kebutuhan pangan. Daya dukung lahan dirasa mengalami penuruhan, hal ini dikarenakan pertumbuhan jumlah penduduk yang semakin meningkat serta lahan menjadi semakin sempit. Untuk meningkatkan daya dukung lahan dapat dilakukan upaya untuk merubah penggunaan lahan ke usaha yang lebih menguntungkan dan disesuaikan dengan karakteristik wilayahnya, serta memanfaatkan teknologi yang ada.

Daya dukung lahan pertanian tidak memiliki besaran yang tetap karena dapat berubah setiap saat akibat pengaruh teknologi dan budaya. Teknologi akan mempengaruhi produktivitas lahan, sedangkan kebudayaan akan menentukan kebutuhan hidup setiap individu. Tingkat daya dukung lahan dipengaruhi oleh faktor perbedaan penduduk, dan pengelolaan sumber daya alam. Perlu adanya progam yang dialokasikan untuk mengelola sumber daya alam yang potensional pada suatu wilayah. Hal ini dimaksudkan agar tidak merusak sumber daya alam dan lingkungan yang ada. Kerusakan sumber daya alam dan lingkungan selama ini disebabkan oleh tingkat pertambahan penduduk dan penyebarannya yang kurang seimbang.

Masalah kerusakan lingkungan yang paling kritis adalah tekanan penduduk terhadap terutama pada sektor pertanian. Masalah ini terus meningkat sejalan dengan waktu karena adanya pertambahan penduduk dan dipakainya terus lahan pertanian untuk pembangunan di sektor non pertanian. Akibatnya, pertumbuhan penduduk dan pemanfaatan lahan pertanian 
untuk pembangunan fisik untuk mendorong masyarakat untuk membuka lahan-lahan pertanian baru yang menjadi salah satu penyebab bencana alam seperti longsor dan banjir (Arifin, 2004)

\section{Memperbaiki Masalah Pembangunan Pertanian}

Untuk menumbuhkan minat generasi jaman ini agar mau menekuni dunia pertanian maka pemerintah harus melakukan pembenahan dalam pembangunan di sektor pertanian. Departemen Pertanian perlu mempertanggungjawabkan kinerjanya terhadap masyarakat dalam urusan ketersedian beras. Bagaimanapun, beras merupakan makanan pokok masyarakat Indonesia, yang harus tersedia setiap saat. Populasi penduduk Indonesia yang saat ini mencapai lebih dari 260 juta jiwa memerlukan tersedianya beras secara lokal dan tidak bisa tergantung pada beras impor. Surplus beras yang diperdagangkan di pasar Internasional hanya sekitar 20 juta ton, sehingga jika terjadi kekurangan supply di pasar Internasional akan menyebabkan Indonesia kesulitan memenuhi kebutuhannya. Beras juga harus mampu terdistribusi secara merata terutama pada daerah yang rawan pangan, mengingat Indonesia merupakan negara kepulauan sehingga perlu diupayakan distribusi beras yang merata.

Bagi orang Indonesia, mengkonsumsi beras dianggap memiliki nilai sosial yang lebih tinggi dibanding mengkonsumsi makanan lain. Konsumsi beras di kalangan masyarakat perdesaan diperkirakan akan terus meningkat. Asumsi masyarakat pedesaan yang masih kental dengan prinsip lebih baik mati berdarah daripada mati kelaparan, membuktikan bahwa peranan beras bagi masyarakat Indonesia masih sangat besar. Beras juga menjadi tolak ukur kestabilan sosial ekonomi dan politik nasional. Konsumen beras perkotaan yang merupakan konsumen beras terbesar kurang peduli terhadap permasalahan beras, mereka cenderung meminggirkan produsen beras dengan penggusuran lahan pertanian untuk dijadikan sebagai pemukiman dan industri.

Indonesia perlu membangun kemandirian dan kedaulatan pangan dengan memanfaatkan sumber daya alam hayati, serta menciptakan industri berbasis pertanian di kalangan perdesaan. Ketahanan pangan Indonesia masih sangat bergantung oleh perdangan internasional, padahal ketersediaan beras di pasar nasional sangatlah tipis. Melihat dari potensi Indonesia yang seharusnya tidak perlu khawatir akan krisis pangan dikarenakan Indonesia memiliki keberagaman sumber daya alam hayati yang berlimpah. Potensi ini dicirikan dengan: 1) kedudukan Indonesia sebagai negara tropis dengan intensitas cahaya matahari yang mumpuni, 2) tersediannya lahan dan air, 3) melimpahnya sumber daya alam hayati, 4) teknologi produksi yang mulai dikembangkan dan diterapkan.

Dengan adanya upaya untuk membangun kemandirian dan kedaulatan sektor pangan diharap Indonesia mampu mengentaskan diri dari krisis pangan. Campur tangan generasi muda sangat diharapkan agar progam ini dapat berjalan dengan baik. Selain mengentaskan diri dari krisis pangan, Indonesia juga harus mampu keluar dari belenggu kemiskinan. Sekitar $67 \%$ penduduk miskin berdomisili di perdesaan, dengan mata pencaharian utama sebagai petani. Dengan demikian pembangunan ekonomi sudah semestinya diorientasikan dari perkotaan ke perdesaan. Pembangunan perdesaan harus dilakukan secara terpadu, dimulai dari sektor pertanian yang ditopang oleh industri pertanian beserta infrastruktur pendukungnya (Saptana \& Rahman, 2015).

Pemerintah perlu melakukan pembenahan agar produksi dan stok beras dalam negeri tetap aman. Beberapa terobosan telah dilakukan pemerintah jaman ini untuk kembali memperkokoh sektor pertanian adalah dengan mengembangkan konsep Food Estate. Food Estate merupakan konsep pengembangan produksi pangan yang dilakukan secara terintregasi mencakup pertanian, perkebunan, bahkan peternakan yang berada di suatu kawasan lahan yang sangat luas ( Tri Wahyu) dalam Gustiana (2015). Daerah untuk Food Estate difokuskan pada daerah di luar pulau Jawa, karena ketersediaan lahan yang masih sangat luas. Daerah yang menjadi target utama adalah Merauke. Kabupaten Merauke telah merencanakan progam MIFE (Merauke Integrated Food and Energy Estate). Daerah 
ini memiliki cadangan lahan pertanian yang luas, mencapai 2,49 ha.

Beberapa keuntungan apabila Food Estate ini dapat telaksana dengan baik diantaranya adalah pemerintah bisa membuka lahan pertanian baru dan dapat meningkatkan produksi tanaman. Menurut mantan Menteri Pertanian, Suswono dalam Wahyunto \& Widiastuti (2014), lahan pertaninan Indonesia mencapai 7 juta ha. Namun di satu sisi terjadi alih fungsi lahan pertanian mencapai 100 ribu ha pertahunnya. Melalui Food Estate diharapkan pemerintah mampu menarik minat investor untuk menggerakkan kegiatan ekonomi. Selain itu Food Estate juga mampu menambah pemasukan negara serta meningkatkan kesejahteraan petani di kawasan Food Estate, dan meningkatkan ketahanan pangan Indonesia. Bukan hanya itu, melalui Food Estate juga diharapkan mampu menyediakan cadangan beras dalam skala yang besar.

Dibalik keuntungan yang diperoleh, Food Estate juga berpotensi menimbulkan kerugian antara lain rakyat tidak bisa memiliki dan mengelola lahan pertanian secara penuh. Mengacu pada Undang-undang No. 25 tahun 2007 tentang Penanaman Modal (UUPM) dan Peraturan Presiden No. 77 tahun 2007 tentang daftar bidang usaha terbuka dan tertutup, yang menyebutkan bahwa investor asing boleh memiliki modal maksimal $95 \%$. Peraturan yang ada nampaknya lebih banyak menguntungkan para investor asing dan merugikan petani dalam negeri. Peraturan yang lahir berpotensi akan memberikan kemudahan dan keluasan bagi penanam modal untuk mengelola Food Estate. Apabila pemerintah tidak mampu melakukan kontrol terhadap distribusi beras hasil Food Estate, besar kemungkinan para pemodal yang akan menjadi penentu harga beras pasar dan ekspor. Pembangunan Food Estate harus mampu membuat negara mengamankan kebutuhan domestik dan cadangan beras nasional.

Apabila masalah ketersediaan beras sudah teratasi, masalah selanjutnya yang harus dibenahi adalah soal distribusi. Saat ini pendapatan petani jauh lebih sedikit ketimbang pendapatan para pedagang, sehingga petani Indonesia masih tergolong miskin. Pada saat terjadi panen raya, harga gabah cenderung anjlok dan merugikan petani. Kondisi geografis Indonesia yang menyebabkan penduduknya terpencar dari satu pulau ke pulau lain menyebabkan perlunya sebuah jaringan pasar untuk mempermudah distribusi. Pembangunan sentra produksi dengan sistem informasi pasar yang transparan dan up to date, termasuk standart kualitas beras yang diinginkan konsumen akan membantu petani meningkatkan kualitas beras.

Di pasar domestik, perlu dibangun terminal dan subterminal agribisnis di sentrasentra produksi yang dapat diakses oleh para petani. Pembangunan jaringan perdagangan ini dimulai dari dibangunnya pasar pengumpul disetiap kecamatan, di tingkat kabupaten dibangun subterminal agribisnis dan di tingkat provinsi dibangun terminal agribisnis (Iskandar) dalam Suseno \& Anas (2017). Semuanya harus saling terkoordinasi satu sama lain, sehingga akan tebentuk jaringan pemasaran yang efektif dan efisien serta menguntungkan semua pihak. Selain itu, supaya produk pertanian dapat di ekspor ke luar negeri dan diakses secara mudah oleh buyer maka perlu dikembangkan Trading House, sehingga jaringan pemasaran hasil pertanian menjadi jelas.

Produk pertanian di pasar domestik masih kurang berkembang. Masyarakat cenderung lebih suka mengkonsumsi makananmakanan impor yang banyak dijual di swalayan. Menurut Iskandar dalam Suseno \& Anas (2017) penguatan pasar domestik mempunyai multiplier effect yang sangat luas dan besar. Dengan penguasaan pasar domestik akan membuka peluang kerja, meningkatkan pendapatan petani, dan membendung kegiatan impor. Selain itu, pembangunan infrastruktur akan berkembang di bidang industri dan jasa. Beberapa upaya perlu dilakukan untuk mendongkrak penguasaan pasar domestik.

Hal pertama yang perlu dilakukan adalah dengan melakukan kampanye kecintaan terhadap produk dalam negeri, hal ini akan meningkatkan minat masyarakat untuk mengkonsumsi makanan-makanan lokal terutama hasil pertanian. Selain itu, perkembangan perdagangan antar wilayah juga perlu dikembangkan, baik antar provinsi maupun antar kabupaten. Perlunya penyediaan sarana pemasaran produksi pertanian di 
Indonesia secara proposional. Pengadaan promosi terhadap produk pertanian juga perlu dilakukan, salah satu caranya adalah dengan pemberian produk pertanian secara cuma-cuma kepada konsumen. Misalnya dengan memberi susu, coklat, telur dan lain-lain kepada anak sekolah.

Salah satu faktor suskses suatu produk adalah keberhasilan dalam menarik minat konsumen. Pemasaran atau pengenalan produk tersebut dapat melalui sarana periklanan, baik melalui televisi, internet, maupun sosial media. Pemerintah dan perusahaan swasta juga harus bisa menjadi pelopor untuk mengkonsumsi hasil pertanian. Misalnya dengan mengkonsumsi rebusan singkong, kacang, pisang, jagung dan sebagainya pada saat rapat, seminar, dan lain-lain. Selain itu, industri pengolahan juga perlu didorong untuk menggunakan bahan baku dari dalam negeri (Delima, Santoso, \& Purwadi, 2016).

Para petani sering kesulitan untuk memperoleh modal guna menggarap sawah mereka. Pembangunan sistem perbankan yang secara terus menerus menjamin pembiayaan sektor pertanian masih belum ada. Kebijakan perbankan lebih banyak mengarah ke sektor industri dan masyarakat perkotaan. Bank Rakyat Indonesia yang dahulu berkiprah di sektor pertanian dan perdesaan kini tak lagi pada kebijakan semula. Di negara yang menjadikan sektor petanian sebagai sektor penting bahkan utama, secara konsisten mendirikan Bank Pertanian. Jika memang Indonesia ingin mengangkat citra pertanian maka pemerintah harus mendirikan Bank Pertanian, terutama di perdesaan.

Dengan melakukan pembenahan di sektor pertanian diharapkan akan mampu meningkatkan kesejahteraan para petani. Pembenahan dan pembangunan perlu diupayakan secara terus menerus dan berkesinambungan, serta dilakukan evaluasi secara berkala agar dapat menambal segala celah yang mengakibatkan kembali terperosotnya sektor pertanian. Apabila pertanian di Indonesia sudah berkembang baik dan stabil, tidak mustahil generasi muda akan tertarik untuk menggeluti sektor pertanian. Namun tidak cukup sampai disitu, penanaman kesadaran juga diperlukan agar banyak orang yang mau dan berminat berkecimpung di bidang pertanian.

\section{Solusi Kelangkaan Petani Masa Depan}

Apabila pembangunan di sektor pertanian telah diupayakan, masalah selanjutnya terletak pada siapa aktor yang akan menggarap lahan tersebut. Memang saat ini Indonesia mencatatkan bahwa petani sebagai profesi yang paling banyak dijalani. Berdasarkan pemantauan Badan Pusat Statistik (BPS) mencatatkan bahwa penduduk yang bekerja di sektor pertanian sebanyak 39,68 juta jiwa, atau 31,86 persen dari jumlah penduduk yang bekerja yang jumlahnya mencapai 124,54 juta jiwa. Dari segi data yang tercatat, sebagian besar penduduk menggantungkan penghasilannya dari pertanian. Saat ini Indonesia masih memiliki puluhan juta petani yang mungkin masih sanggup bekerja untuk 10-20 tahun kedepan. Akan tetapi bagaimana apabila para petani yang semakin bertambah usia mulai memasuki masa purna? Solusinya terletak pada generasi jaman ini. Generasi jaman ini lebih akrab dengan gagdet, sosial media, facebook, whatsapp, dan sebagainya, mereka asing saat memegang cangkul, sabit, bahkan traktor. Sawah tidak bisa diolah secara online, perlu campur tangan secara langsung oleh manusia.

Menumbuhkan minat anak muda untuk mau menggarap sawah sejak dini adalah cara agar kita tidak kekurangan bahan pangan. Peranan guru dan sekolah sangat dominan untuk menumbuhkan kesadaran anak agar tidak melupakan sektor pertanian. Sejak usia sekolah dasar, siswa harus mulai diarahkan untuk mencintai dunia pertanian. Hal ini bukan berarti guru harus memaksakan siswanya untuk menjadi seorang petani. Melalui pembelajaran, guru dapat mengintregasikan potensi Indonesia sebagai negara agraris dalan materi pembelajaran. Dalam mata pelajaran tertentu, guru dapat meminta siswa untuk melakukan wawancara dengan para petani di daerahnya agar mereka dapat mengetahui apa yang petani rasakan. Praktikum secara langsung dengan mengajak siswa untuk berkunjung ke sawah dan berinteraksi dengan para petani serta membantu mereka menanam padi akan menumbuhkan rasa toleransi serta dapat belajar secara langsung dari para petani. 
Guru dapat mendatangkan petani ke dalam kelas untuk mengedukasi para siswa, petani cabai misalnya. Kemudian guru dapat menyediakan ruang di area sekolah untuk siswa dapat berkecimpung secara untuk bercocok tanam. Guru dapat membagi anak dalam beberapa kelompok, kemudian setiap kelompok diminta untuk menanam cabai dengan benar sesuai apa yang telah diajarkan oleh petani cabai di lokasi yang sebelumnya telah disediakan. Mereka dapat merawat lahan mini itu di waktu istirahat, pulang sekolah, atau di jam pelajaran tertentu. Apabila cabai berhasil berbuah guru meminta siswa untuk memasarkan cabai tersebut. Guru-guru yang lain juga dapat membeli secara langsung cabai yang diproduksi siswa dengan harga sesuai pasaran. Uang yang terkumpul seutuhnya milik kelompok. Apabila siswa sudah merasa berhasil dan mampu menghasilkan uang dari usahanya di bidang pertanian, maka minat siswa untuk mau menggeluti bidang pertanian pun akan mulai tumbuh.

Cara lain yang dapat guru tempuh adalah dengan mengikut sertakan siswanya untuk mengikuti seminar atau workshop yang berhubungan dengan pertanian. Kegiatan ini lebih diarahkan untuk siswa usia sekolah menengah atas. Mengubah paradigma yang semula menggap petani adalah pekerjaan yang kurang menguntungkan dan tidak keren bagi anak muda perlu diupayakan oleh guru. Penggunaan alat-alat modern seperti traktor dan transplanter yang mempermudah proses pertanian juga akan mampu menarik minat generasi anak muda. Apabila proses mengolah sawah lebih mudah dan lebih masa kini dengan penggunaan teknologi bukan tidak mungkin jika anak muda mau menekuni sektor pertanian.

Dengan memberdayakan anak putus sekolah atau anak jalanan untuk bisa lebih produktif dengan menjadi petani adalah salah satu upaya yang baik. Anak jalanan sering dianggap negatif oleh masyarakat, mereka dianggap sebagai anak yang mengganggu ketertiban umum dengan tidak sekolah, bermain dan mencari nafkah di jalan. Beberapa faktor yang menyebabkan adanya anak jalanan antara lain disfungsi keluarga, kemiskinan, dan kekerasan dalam keluarga. Anak putus sekolah dan anak jalanan sejatinya tetap merupakan anak-anak yang harus dilindungi oleh negara, hal ini tertuang dalam UUD 1945 pasal 34. Anak jalanan sejatinya perlu diberdayakan agar mereka terhindar dari segala bentuk eksploitasi yang ada.

Perlu adanya upaya yang dilakukan oleh pemerintah untuk mengentaskan anak jalanan. Pemerintah sejatinya kurang memperhatikan kondisi anak jalanan yang semakin marak karena anak jalanan dianggap sebagai pembuat masalah, bukan sebagai korban. Anak jalanan sejatinya dapat diberdayakan untuk menyokong sektor pertanian, mereka dapat diberi pengetahuan tentang pertanian meliputi pembenihan, persiapan lahan, pengolahan lahan, penanaman, sampai dengan pemasaran. Perlu adanya wadah atau progam untuk anak jalanan dapat memperoleh pelatihan. Progam ini dapat dilaksanan oleh berbagai pihak diantaranya pemerintah, organisasi non pemerintah, akademisi, pers dan masyarakat. Jalinan kerjasama antar seluruh elemen, bila dapat terbangun dengan baik, merupakan faktor utama yang akan berperan besar di dalam mencapai keberhasilan untuk memberikan perlindungan, pemenuhan hak anak, dan pemberdayaan anak jalanan ke arah yang positif khususnya di sektor pertanian.

\section{SIMPULAN}

Umumnya mereka yang ingin menjadi petani adalah anak-anak yang tidak ingin melanjutkan ke sekolah tinggi, dan tidak ada pilihan pekerjaan lain. Pemerintah dapat memberdayakan anak-anak muda yang tidak mampu melanjutkan sekolah ke jenjang berikutnya bahkan putus sekolah. Dengan memberi mereka pelatihan secara eksplisit anak-anak ini akan mampu menjadi petani masa depan dan menekan angka pengangguran di Indonesia. Guru bahkan orang tua tidak berhak untuk memaksakan cita-cita anak, tetap berikan mereka kebebasan untuk menjadi apa yang mereka inginkan. Namun mereka juga perlu diberi edukasi bagaimana proses satu piring nasi bisa mereka santap setiap hari.

Dengan melakukan pembenahan pembangunan terlebih dahulu di sektor pertanian serta adanya jaminan kesejahteraan bagi para petani diharap minat anak muda akan 
lebih terjaring. Peranan guru dan sekolah untuk mengenalkan dan membuat anak mencintai dunia pertanian akan lebih berpotensi untuk mencetak petani di generasi jaman ini dan guna pemenuhan petani masa depan.

\section{DAFTAR PUSTAKA}

Arifin, B. (2004). Analisis Ekonomi Pertanian Indonesia. Jakarta: kompas.

Delima, R., Santoso, H. B., \& Purwadi, J. (2016). Kajian Aplikasi Pertanian yang Dikembangkan di Beberapa Negara Asia dan Afrika. Seminar Nasional Aplikasi Teknologi Informasi (SNATi), 19-26. https://doi.org/10.1177/014303431140681 2

Gustiana, C. (2015). Strategi Pembangunan Pertanian dan Perekonomian Pedesaan Melalui Kemitraan Usaha Berwawasan Agrabisnis. AGRISAMUDRA, Jurnal Penelitian, 2(1), 71-80.
Ningsih, E. A., \& Kurniawan, W. (2016). Daya Saing Dinamis Produk Pertanian Indonesia di ASEAN. JURNAL EKONOMI KUANTITATIF TERAPAN Vol., 9(2), 117-125.

Saptana, \& Rahman, H. P. S. (2015). Tujuan Konseptual Makro-Mikro Pemasaran dan Implikasinya Bagi Pembangunan Pertanian. FORUM PENELITIAN AGRO EKONOM, 33(2), 127-148.

Suseno, D. A., \& Anas, M. A. (2017). Multiplier Effect Sektor Basis Terhadap Perekonomian Daerah Provinsi Jawa Tengah. Jurnal Riset Ekonomi Pembangunan Volume, 2(2), 113-126.

Wahyunto, \& Widiastuti, F. (2014). Lahan Sawah Sebagai Pendukung Ketahanan Pangan serta Strategi Pencapaian Kemandirian Pangan. Jurnal Sumberdaya Lahan Edisi Khusus, 17-30. 